\title{
Effects of Composite $\beta$ - and k-Casein Genotypes on Milk Coagulation, Quality, and Yield Traits in Italian Holstein Cows
}

\author{
A. Comin, ${ }^{*}$ M. Cassandro, ${ }^{* 1}$ S. Chessa, † M. Ojala,‡ R. Dal Zotto, ${ }^{*}$ M. De Marchi, ${ }^{*}$ P. Carnier, ${ }^{*}$ L. Gallo, ${ }^{*}$ \\ G. Pagnacco, $†$ and G. Bittante* \\ *Department of Animal Science, University of Padova, Viale dell'Università 16, 35020 Legnaro, Padova, Italy \\ †Department of Veterinary Science and Technology for Food Safety, University of Milano, via Celoria, 10, Italy \\ ‡Department of Animal Science, University of Helsinki, PO Box 28, 00014 Helsinki, Finland
}

\begin{abstract}
The aim of the study was to estimate the effect of the composite CSN2 and CSN3 genotypes on milk coagulation, quality, and yield traits in Italian Holstein cows. A total of 1,042 multiparous Holstein cows reared on 34 commercial dairy herds were sampled once, concurrently with monthly herd milk recording. The data included the following traits: milk coagulation time; curd firmness; $\mathrm{pH}$ and titratable acidity; fat, protein, and casein contents; somatic cell score; and daily milk, fat, and protein yields. A single-trait animal model was assumed with fixed effects of herd, days in milk, parity, composite casein genotype of CSN2 and CSN3 (CSN2CSN3), and random additive genetic effect of an animal. The composite genotype of CSN2-CSN3 showed a strong effect on both milk coagulation traits and milk and protein yields, but not on fat and protein contents and other milk quality traits. For coagulation time, the best CSN2-CSN3 genotypes were those with at least one B allele in both the CSN2 and CSN3 loci. The CSN3 locus was associated more strongly with milk coagulation traits, whereas the CSN2 locus was associated more with milk and protein yields. However, because of the tight linkage between the 2 loci, the composite genotypes, or haplotypes, are more appropriate than the single-locus genotypes if they were considered for use in selection.
\end{abstract}

Key words: casein genotype, milk coagulation, dairy cattle, Holstein breed

\section{INTRODUCTION}

Cheese-making ability of milk plays a fundamental role in cheese production, especially for hard and longripened cheeses. This characteristic of milk has a great impact in Italy (De Marchi et al., 2007), where the

Received July 25, 2007.

Accepted June 26, 2008.

${ }^{1}$ Corresponding author: martino.cassandro@unipd.it cheese-making industry uses about $70 \%$ of the overall milk production (ISTAT, 2005). In milk-to-cheese steps, coagulation of milk is important and sensitive because it is the first phase and affects the following phases in the process. Therefore, the recording data and genetic evaluation of milk for cheese production can be effectively done by using milk coagulation properties (MCP) such as milk coagulation time, curd-firming time, and curd firmness (Aleandri et al., 1989).

Genetic improvement of MCP is a confirmed tool to improve the efficiency of cheese production (Caroli et al., 1988; Ikonen, 2000; Bittante et al., 2002), but the lack of suitable equipment for their routine determination and recording restricts the possibility of direct selection of breeding animals for the trait. Alternatively, an indirect selection approach to improve MCP might be to increase the frequency of alleles in milk protein loci that are associated with better coagulation of milk (Ikonen, 2000), just as the casein complex has already been used in marker-assisted selection (Boettcher et al., 2004).

Casein polymorphisms have been known as factors affecting milk composition, both because of their qualitative variation - related to single gene mutations - and their quantitative variation, concerning the differences in allele expression implicated in milk protein synthesis (Ikonen et al., 1997; Mayer et al., 1997). According to the literature, and the nomenclature suggested by the COGNOSAG ad hoc committee (1995), loci involved in the casein complex showed that $\alpha_{\mathrm{s} 1}$-casein (CSN1S1) and $\alpha_{\mathrm{s} 2}$-casein (CSN1S2) influence protein content significantly (Aleandri et al., 1986; Ng-Kwai-Hang et al., 1986, whereas k-casein (CSN3) affects casein content (Ng-Kwai-Hang et al., 1984, 1986), protein content (Ng-Kwai-Hang et al., 1984; Aleandri et al., 1986, 1990; Ikonen et al., 1999b), and cheese yield (Mariani et al., 1976; Aleandri et al., 1990) as well as curd firmness (Marzali and Ng-Kwai-Hang, 1986; Pagnacco and Caroli, 1987; Davoli et al., 1990; Ikonen et al., 1999a). Moreover, B-casein (CSN2) was found to be associated with fat percentage, fat and protein yields (Ng-Kwai- 
Hang et al., 1984), and curd firmness (Politis and Ng-Kwai-Hang, 1988; Ikonen et al., 1999b). Moreover, several findings are reported in the recent literature of QTL on chromosome 6 affecting milk traits (Gallagher et al., 1994; Freyer et al., 2003).

Despite the large number of studies regarding the effects of milk protein polymorphism on milk composition, findings are sometimes inconsistent and difficult to compare because of differences in the size of data sets, breed of animals, and because both fixed and mixed models were employed (Aleandri et al., 1990; Bovenhuis et al., 1992; Kennedy et al., 1992). Mixed models are recommended because they allow the separation of the effect of casein genotypes from the additive polygenic effect of animals by including a random animal effects and a genetic relationship matrix in the model (Kennedy et al., 1992). Another possible bias in estimation of milk protein genotype effects could be due to the inclusion of single casein genotypes in the model separately or simultaneously. Bovenhuis et al. (1992) observed that the concurrent insertion of different casein loci (CSN1S1, CSN2, and CSN3) in the model produced more accurate estimates of their effect compared with the inclusion of a single locus at a time. Moreover, physical mapping techniques confirmed a close linkage between the caseins, establishing that the casein loci reside on chromosome 6 within a region of $<250$ $\mathrm{kb}$ in the order of CSNS1, CSN2, CSN1S2, and CSN3 (Ferretti et al., 1990; Threadgill and Womack, 1990; Martin et al., 2002). Ojala et al. (1997) suggested that allelic effects at each locus are confounded in statistical analyses, even when they are included simultaneously in the model. Consequently, the effects of casein genotypes should be estimated using composite casein genotypes of CSN2 and CSN3 (CSN2-CSN3) instead of separate genotypes, as suggested by Ojala et al. (1997) and confirmed by Ikonen et al. (1999b).

The aim of this study was to investigate the effects of CSN2-CSN3 composite genotypes on milk coagulation, quality, and yield traits in Holstein cows reared in Northern Italy, taking into account the additive polygenic background of animals.

\section{MATERIALS AND METHODS}

\section{Data and Traits Studied}

A total of 1,042 multiparous Holstein cows reared in 34 commercial dairy herds were sampled once, concurrently with monthly herd milk recording. The data included the following traits: milk coagulation time $(\mathbf{R C T})$, curd firmness $\left(\mathbf{a}_{30}\right), \mathrm{pH}$, titratable acidity (TA), fat, protein, and casein contents, SCS, and daily milk, fat, and protein yields. Details of data collection and laboratory analyses for milk coagulation, production, and quality traits are described by Cassandro et al. (2008). The casein genetic variants at CSN1S1, CSN1S2, CSN2, and CSN3 loci were determined by isoelectric focusing analysis (Erhardt, 1989; Erhardt et al., 1998).

\section{Statistical Analyses}

The milk samples that did not coagulate in $31 \mathrm{~min}$ ( $10 \%$ of the samples analyzed) supplied no suitable information about MCP, so they were excluded from the statistical analyses. Further data editing aimed to discard records with sampling or recording errors such as protein content $<1.5 \%$ or $>5.0 \%$ and fat content out of the range 1.5 to $7.0 \%$.

In preliminary analyses, the GLM procedure of SAS (SAS Institute, 2000) was used to test the statistical significance of fixed effects (herd, DIM, parity, month, or season) of the linear model. Data were recorded during a single year from January to July. The effects of season or month of recording were not statistically significant. Thus, these effects were not included in the final linear model. Therefore, the CSN2-CSN3 composite genotype effects on milk coagulation, quality, and yield traits were investigated using the following single-trait animal model:

$$
\begin{gathered}
\mathrm{y}_{\mathrm{ijklmn}}=\mu+\operatorname{herd}_{\mathrm{i}}+\operatorname{dim}_{\mathrm{j}}+\text { parity }_{\mathrm{k}}+\text { CSN2-CSN3 } \\
+\operatorname{anim}_{\mathrm{m}}+\varepsilon_{\mathrm{ijklmn}},
\end{gathered}
$$

where $\mathrm{y}_{\mathrm{ijk} l \mathrm{mn}}=$ milk coagulation $\left(\mathrm{RCT}, \mathrm{a}_{30}\right)$ or yield traits; $\mu$ = general mean; herd $_{\mathrm{i}}=$ fixed effect of herd ( $\mathrm{i}=$ 1 to 34$) ; \operatorname{dim}_{\mathrm{j}}=$ fixed effect of DIM ( $\mathrm{j}=1$ to 14$) ;$ parity $_{\mathrm{k}}$ $=$ fixed effect of parity $(\mathrm{k}=1$ to 3$) ; \mathrm{CSN} 2-\mathrm{CSN}_{1}=$ fixed effect of composite CSN2-CSN3 genotype ( $1=1$ to 16$)$; $\operatorname{anim}_{\mathrm{m}}=$ random additive genetic effect of an animal, $\mathrm{N}\left(\mathbf{0}, \mathbf{A} \boldsymbol{\sigma}_{\mathrm{a}}^{2}\right)$; and $\varepsilon_{\mathrm{ijklmn}}=$ random residual effect, $\mathrm{N}\left(\mathbf{0}, \mathbf{I} \boldsymbol{\sigma}_{\mathbf{e}}^{2}\right)$.

Days in milk were grouped into 14 classes: 10 monthly classes until $300 \mathrm{~d}, 3$ two-monthly classes until 480 $\mathrm{d}$, and 1 open class containing the lactations exceeding $480 \mathrm{~d}$ after calving. Parity was divided into 3 classes: first, second, and third to seventh calving. Missing information about days in milk and parity occurred for 29 cows, so these records were discarded. The final number of records included in the study was 1,042 .

Because of the low frequency of some CSN2-CSN3 composite genotypes (Table 1), all subclasses accounting for $<1 \%$ of observations ("rare" class) were grouped together. The number of CSN2-CSN3 genotype classes 
Table 1. Number of cows for the CSN2 and CSN3 genotypes and observed and expected frequencies (upper and lower line respectively, each given as percentage) of the composite CSN2-CSN3 genotypes in 973 Italian Holstein cows

\begin{tabular}{|c|c|c|c|c|c|c|c|c|}
\hline \multirow{2}{*}{$\begin{array}{l}\text { CSN3 } \\
\text { genotype }\end{array}$} & \multirow[b]{2}{*}{$\mathrm{n}$} & \multicolumn{7}{|c|}{ CSN2 genotype (n) } \\
\hline & & $A_{1} / A_{1}(120)$ & $A_{1} / A_{2}(434)$ & $A_{1} / B(40)$ & $A_{2} / A_{2}$ (309) & $A_{2} / A_{3}(5)$ & $A_{2} / B(62)$ & $B / B(3)$ \\
\hline$A / A$ & & 5.6 & 20.1 & 1.9 & 14.3 & 0.2 & 2.9 & 0.1 \\
\hline \multirow[t]{2}{*}{$A / B$} & 325 & 2.7 & 12.3 & 3.1 & 10.0 & 0.1 & 5.2 & \\
\hline & & 4.1 & 14.9 & 1.4 & 10.6 & 0.2 & 2.1 & 0.1 \\
\hline$A / E$ & 140 & 3.5 & 10.6 & & 0.3 & & & \\
\hline$B / B$ & & 0.5 & 1.9 & 0.2 & 1.3 & & 0.3 & \\
\hline \multirow[t]{2}{*}{$B / E$} & 16 & 0.3 & 1.0 & 0.2 & 0.1 & & & \\
\hline & & 0.2 & 0.7 & 0.1 & 0.5 & & 0.1 & \\
\hline \multirow[t]{2}{*}{$E / E$} & 13 & 0.5 & 0.4 & 0.1 & 0.3 & & & \\
\hline & & 0.2 & 0.6 & 0.1 & 0.4 & & 0.1 & \\
\hline
\end{tabular}

totaled 16, including rare and unknown genotypes (Table 2). For 69 samples, it was not possible to determine the exact genotype; however, they were randomly distributed among herds and sires, so we grouped them all together (into an "unknown" class) and kept them in the analyses to avoid loss of information. The relationship matrix $\mathbf{A}$ included cows with observations and their known ancestors up to 8 generations back in the pedigree, with a total of 7,387 animals.

The PEST package (Groeneveld, 1990) was used for estimating effects of CSN2-CSN3 genotypes and their statistical significance via $F$-test. The null hypothesis tested was any difference among genotype classes. When testing the genotypes, the $\mathrm{CSN}^{*}{ }_{2} A_{2} / A_{2-}$
CSN3* $A / A$ genotype $\left(A_{2} / A_{2}-A / A\right)$ was used as the class of comparison because it was the class with the largest number of observations and the composite genotype was homozygous for both loci. It follows that the standard errors of the genotype effects are standard errors of the differences between each genotype and the most frequent $A_{2} / A_{2}-A / A$ genotype.

\section{RESULTS AND DISCUSSION}

\section{$\beta$ - and $\mathrm{k}$-Casein Genotypes}

The most frequent CSN2 genotypes were $A_{1} A_{2}$ and $A_{2} A_{2}$, whereas $A A$ and $A B$ were the most common for

Table 2. Estimated effects (Est.) and their standard errors (SE) of CSN2-CSN3 composite genotypes on milk coagulation traits [milk coagulation time (RCT) and curd firmness $\left(\mathrm{a}_{30}\right)$ ], and milk and protein yields given as a deviation of the most frequent genotype $A_{2} / A_{2}-A / A$

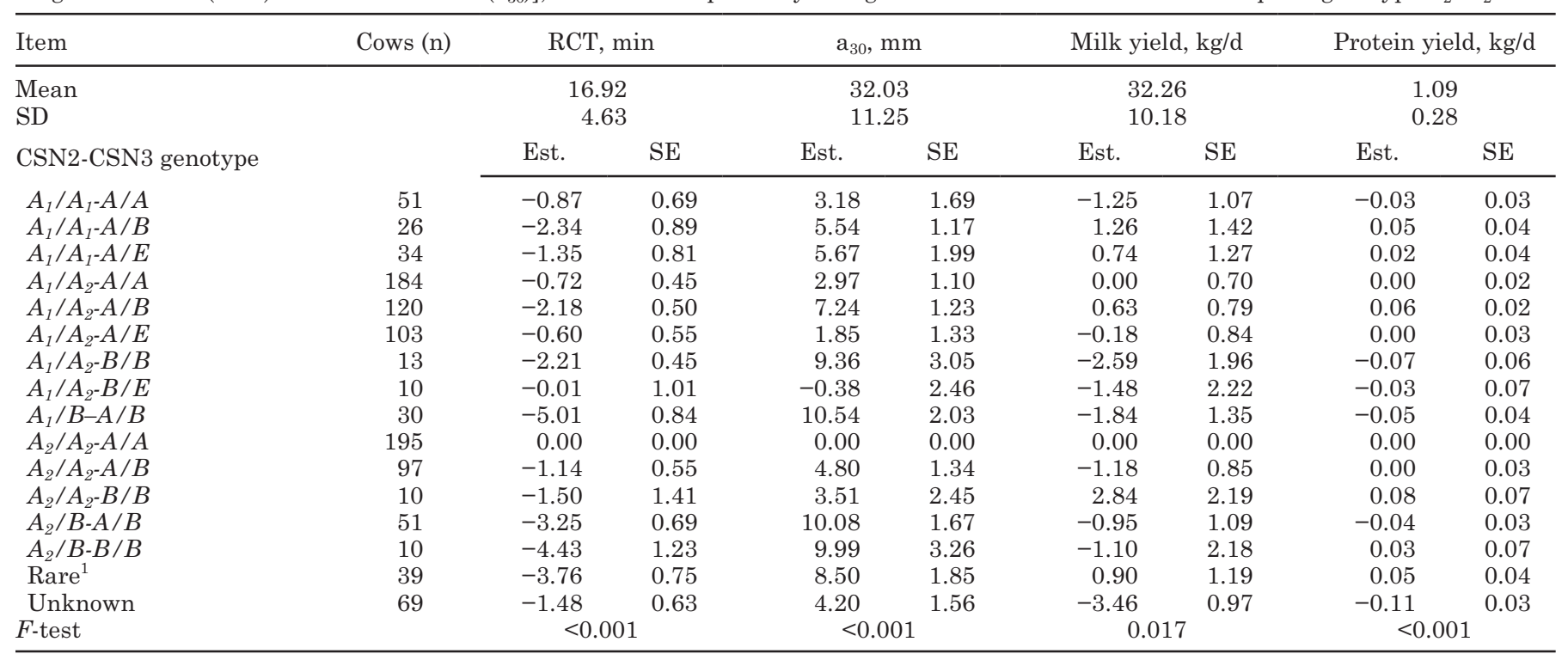

${ }^{1}$ Composite genotypes accounting for $<1 \%$ of observations were grouped together as rare: $A_{1} / A_{1}-B / B(\mathrm{n}=1) ; A_{1} / A_{1}-B / E(\mathrm{n}=4) ; A_{1} / A_{1}-E / E$ $(\mathrm{n}=5) ; A_{1} / A_{2}-E / E(\mathrm{n}=4) ; A_{1} / B-B / B(\mathrm{n}=6) ; A_{1} / B-B / E(\mathrm{n}=2) ; A_{1} / B-E / E(\mathrm{n}=1) ; A_{2} / A_{2}-A / E(\mathrm{n}=3) ; A_{2} / A_{2}-B / E(\mathrm{n}=1) ; A_{2} / A_{2}-E / E(\mathrm{n}=3) ;$ $A_{2} / A_{3}-A / A(\mathrm{n}=4) ; A_{2} / A_{3}-A / B(\mathrm{n}=1) ; A_{2} / B-A / A(\mathrm{n}=1) ;$ and $B / B-B / B(\mathrm{n}=3)$. 
CSN3 (Table 1). The most frequent composite genotype was $A_{2} / A_{2}-A / A$, followed by $A_{1} / A_{2}-A / A$; together they constituted almost a half of the data. The $A_{2} / A_{3}$ and $B / B$ genotypes of CSN2 as well as $B / E$ and $E / E$ genotypes of CSN3 were very rare and never occurred together as a combination. The evidence that some alleles at one locus are associated only with certain alleles at the other locus was confirmed by the differences between observed and expected frequencies of CSN2-CSN3 composite genotypes $(P<0.0001$; Table 1). In particular, the observed frequencies of $A_{1} / A_{1^{-}}$ $A / E, A_{1} / A_{2}-A / E, A_{1} / B-A / B$, and $A_{2} / B-A / B$ genotypes were twice as high as expected, whereas the observed frequencies of $A_{1} / A_{1}-A / B, A_{2} / A_{2}-A / E$, and $A_{2} / A_{2}-B / E$ genotypes were less than one-half of the expected frequency.

These results might be due to the typical data structure of dairy cow populations under intense selection that use AI with a few sires producing a large number of daughters. In this case, the unbalances in genotype and allele frequencies are a result of selection and the low number of sires that might have produced a low genetic diversity in the sample. Some authors suggested that, in this case, a possible linkage disequilibrium or gametic phase disequilibrium in the CSN2 and CSN3 loci might be due to the extremely unbalanced data that can also be produced and maintained by selection favoring one combination of alleles over another (e.g., Falconer and Mackay, 1996). Linkage disequilibrium between the CSN2 and CSN3 loci was reported in Finnish Ayrshire cattle by Ikonen et al. (1999a).

\section{Effects of Composite CSN2-CSN3 Genotypes}

The present study investigated the role of the association of CSN2 and CSN3 genotypes on milk coagulation (RCT, $\mathrm{a}_{30}, \mathrm{pH}, \mathrm{TA}$ ), quality (SCS, fat, protein, and casein contents), and yield traits (milk, protein, and fat yields).

MCT. Milk coagulation traits ( $\mathrm{RCT}$ and $\mathrm{a}_{30}$ ), and milk and protein yields were affected by CSN2-CSN3 genotypes $(P<0.01$; Table 2$)$. The most favorable MCP were associated with the CSN2-CSN3 composite genotypes containing at least one $B$ allele in both loci: $A_{1} / B-A / B$, $A_{2} / B-B / B$, and $A_{2} / B-A / B$ (Table 2). The most frequent genotype, $A_{2} / A_{2}-A / A$, and the genotypes $A_{1} / A_{2}-B / E$ and $A_{1} / A_{2}-A / E$ were instead associated with poorly coagulating milk. The $C S N 3^{*} E$ allele rarely occurred in association with CSN2 $A_{2} / A_{2}$ and $A_{2} / B$ genotypes (Table 1) and combined with the other CSN2 genotypes. The $\operatorname{CSN}^{*} E$ allele occurring in the CSN2-CSN3 composite genotype was associated with the worst MCP, as previously assessed by Ikonen et al. (1999a) in the Finnish Ayrshire. Considering the remaining CSN3 alleles, $\operatorname{CSN}^{*} B$ was the most favorable (better than $\mathrm{CSN}^{*} A$ ) for MCP, in every combination with CSN2 genotypes. Similar results were found for CSN2 locus, where the $C S N 2^{*} A_{1}$ allele showed the most favorable effect (superior to $\mathrm{CSN}^{*} \mathrm{~A}_{2}$ ).

The composite CSN2-CSN3 genotypes including the $\mathrm{CSN}^{*} \mathrm{~B}$ allele were also associated with the best MCP in the Finnish Ayrshire cattle (Ikonen et al., 1999a; Ojala et al., 2005), but the CSN2 locus in that population did not include the $C S N 2 * B$ allele. The same authors also reported the important role of CSN3 locus on MCP, but because of the lack of $C S N 2^{*} B$ alleles in their sampled population, other comparisons with their study are not possible. Comparing both casein loci, it seems that $C S N 3$ affected milk coagulation traits more than $C S N 2$, even if the $C S N 2 * B$ allele turned out to be more favorable for milk coagulation than the $\operatorname{CSN} 2^{*} A_{1}$ and $\mathrm{CSN}^{*} \mathrm{~A}_{2}$ alleles. The previous result may be related to the early report by Waugh and von Hippel (1956) in which CSN3 had an important effect on the stabilization of casein micelles.

Milk and Protein Yields. The CSN2-CSN3 genotypes did not have a statistically significant effect on fat yield $(P=0.07)$, and fat $(P=0.72)$, protein $(P=$ $0.15)$, and casein $(P=0.34)$ contents, SCS $(P=0.55)$, and acidity of milk (for $\mathrm{pH}: P=0.76$; for TA: $P=0.38$ ). The greatest milk and protein yields were related to the rare $A_{2} / A_{2}-B / B$ and $A_{1} / A_{1}-A / B$ genotypes, whereas the smallest yields were associated with genotypes $A_{1} / A_{2}-B / B$ and $A_{1} / B-A / B$ (Table 2). Thus, the most favorable composite genotype for milk and protein yields differed from the least favorable genotype only by having the $C_{S N}{ }^{*} A_{2}$ allele instead of $C S N 2 * A_{1}$ allele. A single allele switch was also the only difference between the second-most and second-least favorable genotypes (CSN2* $A_{1}$ instead of $C S N 2^{*} B$, in this case). It seems that CSN2 locus has a strong effect on milk and protein yields, and the positive effect decreases in the order of $C S N 2^{*} A_{2}>C S N 2^{*} A_{1}>C S N 2^{*} B$ alleles. Furthermore, the CSN2 alleles tend to have an opposite effect on yield and coagulation traits, meaning that the most favorable alleles for milk and protein yields lead to milk less suitable for cheese making. The role of the CSN3 genotypes on yield traits was unclear because of apparent interaction, with the stronger effect of the CSN2 genotypes (but no statistically significant effect was tested). For example, the $C S N 3^{*} B / B$ genotype of CSN3 was favorable for milk and protein yields when associated with the $A_{2} / A_{2}$ and $A_{2} / B$ genotypes of CSN2, but it became unfavorable when associated with $A_{1} / A_{2}$. Similarly, the CSN3 genotype $A / B$ was favorable for milk and protein yields if combined with CSN2 genotypes $A_{1} / A_{1}, A_{1} / A_{2}$, and $A_{2} / A_{2}$, but not in association with $A_{1} / B$ and $A_{2} / B$. The effect of CSN2 
locus on milk yield traits being superior over the effect of the CSN3 locus has been reported previously by several authors (e.g., Aleandri et al., 1990; Bovenhuis et al., 1992; Freyer et al., 1999; Ikonen et al., 1999b).

The positive effect of the rare $A_{2} / A_{2}-B / B$ genotype; that is, the $A_{2} / B$ haplotype, on milk and protein yields was also reported in the previous studies on both Californian Holstein (Ojala et al., 1997) and Finnish Ayrshire cows (Ikonen et al., 1999b, 2001). A strong effect of CSN2 genotype on milk and protein yield was also reported by Ng-Kwai-Hang et al. (1984) and Ikonen et al. (1999a). The CSN3 genotypes had no clear effect on production traits in this study, which is in agreement with previous studies (Aleandri et al., 1990; Davoli et al., 1990; Ikonen et al., 1999b), but the finding of no significant effect of CSN3 genotypes on protein percentage in this study disagrees with the literature. A possible explanation for the result could reside in the limited size and the structure of the data set, and consequently in the limited number of observations within the majority of the composite CSN2-CSN3 genotypes. Moreover, the evidence that the most frequent CSN2CSN3 genotype $\left(A_{2} / A_{2}-A / A\right)$, the $A_{2} / A$ haplotype, was associated with slightly greater milk and protein yields and with slightly poorer MCP, could be explained, in part, as a result of past breeding schemes in Italian Holstein population, which were mainly focused on milk production rather than milk quality and coagulation ability.

\section{CONCLUSIONS}

The CSN2-CSN3 composite genotypes were associated with both milk coagulation and yield traits. For coagulation time and curd firmness, the best CSN2CSN3 composite genotypes were those with at least one $\mathrm{B}$ allele at both loci $\left(A_{1} / B-A / B, A_{2} / B-B / B\right.$, and $\left.A_{2} / B-A / B\right)$, whereas for milk and protein yield, the best genotype was the most frequent genotype $\left(A_{2} / A_{2}-A / A\right)$. The CSN3 locus was associated more strongly with milk coagulation traits, whereas the CSN2 locus was associated more with milk and protein yields. The tight linkage between the 2 loci means that the composite genotypes, or haplotypes, are the most appropriate set of information if these loci are to be considered for use in selection decisions.

\section{ACKNOWLEDGMENTS}

The authors thank PRIN 2003 project (2003078003_002 and 20030708003_004) for financial support. The authors thank referees for the useful suggestions to improve the manuscript.

\section{REFERENCES}

Aleandri, R., L. G. Buttazzoni, J. C. Schneider, A. Caroli, and R. Davoli. 1990. The effects of milk protein polymorphisms on milk components and cheese-production ability. J. Dairy Sci. 73:241255.

Aleandri, R., A. Nardone, and V. Russo. 1986. Milk yield for the cheesemaking process: Quantitative traits, loci, and selection strategies. 3rd World Congr. Genet. Appl. Livest. Prod. XII (64). Univ. Nebraska, Lincoln.

Aleandri, R., J. C. Schneider, and L. G. Buttazzoni. 1989. Evaluation of milk for cheese production based on milk characteristics and Formagraph measures. J. Dairy Sci. 72:1967-1975.

Bittante, G., M. Marusi, F. Cesarini, M. Povinelli, and M. Cassandro. 2002. Genetic analysis on milk rennet-coagulation ability in Italian Holstein cows. Proc. 7th World Congr. Genet. Appl. Livest. Prod., Montpellier, France. CD Commun. No. 09-03.

Boettcher, P. J., A. Caroli, A. Stella, S. Chessa, E. Budelli, F. Canavesi, S. Ghiroldi, and G. Pagnacco. 2004. Effects of casein haplotypes on milk production traits in Italian Holstein and Brown Swiss cattle. J. Dairy Sci. 87:4311-4317.

Bovenhuis, H., J. A. M. van Arendonk, and S. Korver. 1992 Associations between milk protein polymorphism and milk production traits. J. Dairy Sci. 75:2549-2559.

Caroli, A., P. Bolla, G. Pagnacco, M. Rampilli, and L. Degano. 1988. Repeatability of milk clotting evaluated by thelactodynamographic analysis. J. Dairy Res. 57:141-142.

Cassandro, M., A. Comin, M. Ojala, R. Dal Zotto, M. De Marchi, L. Gallo, P. Carnier, and G. Bittante. 2008. Genetic parameters of milk coagulation properties and their relationships with milk yield and quality traits in Italian Holstein cows. J. Dairy Sci. 91:371-376.

COGNOSAG ad hoc committee. 1995. Revised guidelines for gene nomenclature in ruminants 1993. Genet. Sel. Evol. 27:89-93.

Davoli, R., S. Dall'Olio, and V. Russo. 1990. Effect of K-casein genotype on the coagulation properties of milk. J. Anim. Breed. Genet. 107:458-464.

De Marchi, M., R. Dal Zotto, M. Cassandro, and G. Bittante. 2007. Milk coagulation ability of five dairy cattle breeds. J. Dairy Sci. 90:3986-3992.

Erhardt, G. 1989. к-Casein in bovine milk. Evidence of a further allele (к-CnE) in different breeds. J. Anim. Breed. Genet. 106:225-231.

Erhardt, G., J. Juszczak, L. Panicke, and H. Krick-Saleck. 1998. Genetic polymorphism of milk proteins in Polish Red cattle: A new genetic variant of beta-lactoglobulin. J. Anim. Breed. Genet. 115:63-71.

Falconer, D. S., and T. F. C. Mackay. 1996. Introduction to Quantitative Genetics. 4th ed. Longman Group Ltd., Essex, UK.

Ferretti, L., P. Leone, and V. Sgaramella. 1990. Long range restriction analysis of the bovine casein genes. Nucleic Acids Res. 18:68296833.

Freyer, G., Z. Liu, G. Erhard, and L. Panicke. 1999. Casein polymorphism and relation between milk production traits. J. Anim. Breed. Genet. 116:87-97.

Freyer, G., P. Sorensen, C. Kuhn, R. Weikard, and I. Hoeschele. 2003. Search for pleiotropic QTL on chromosome BTA6 affecting yield traits of milk production. J. Dairy Sci. 86:999-1008.

Gallagher, D. S., C. P. Schelling, M. M. Groenen, and J. E. Womack. 1994. Confirmation that the casein gene cluster resides on cattle chromosome 6. Mamm. Genome 5:525. (Abstr.)

Groeneveld, E. 1990. PEST User's Manual. Inst. Anim. Husbandry Anim. Behav., Fed. Agric. Res. Ctr., Neustadt, Germany.

Ikonen, T. 2000. Possibilities of genetic improvement of milk coagulation properties of dairy cows. PhD Diss. Univ. Helsinki, Finland. Available: http://ethesis.helsinki.fi/julkaisut/maa/kotie/ vk/ikonen.

Ikonen, T., K. Ahlfors, R. Kempe, M. Ojala, and O. Ruottinen. 1999a. Genetic parameters for the milk coagulation properties and prevalence of noncoagulating milk in Finnish dairy cows. J. Dairy Sci. 82:205-214. 
Ikonen, T., H. Bovenhuis, M. Ojala, O. Ruottinen, and M. Georges. 2001. Associations between casein haplotypes and first lactation milk production traits in Finnish Ayrshire cows. J. Dairy Sci. 84:507-514.

Ikonen, T., M. Ojala, and O. Ruottinen. 1999b. Association between milk protein polymorphism and first lactation milk production traits in Finnish Ayrshire cows. J. Dairy Sci. 82:1026-1033.

Ikonen, T., M. Ojala, and E. L. Syväoja. 1997. Effects of composite casein and B-lactoglobulin genotypes on renneting properties and composition of bovine milk by assuming an animal model. Agric. Food Sci. Finl. 6:283-294.

ISTAT (Istituto Nazionale di Statistica). 2005. Censimento dell'agricoltura, indagine sui prodotti lattiero-caseari in Italia, in 2005. Online: http://www.istat.it.

Kennedy, B. W., M. Quinton, and J. A. M. van Arendonk. 1992. Estimation of effects of single genes on quantitative traits. J. Anim. Sci. 70:2000-2012.

Mariani, P., G. Losi, V. Russo, G. B. Castagnetti, L. Grazia, D. Morini, and E. Fossa. 1976. Prove di caseificazione con latte caratterizzato dalle varianti A e B della k-caseina nella produzione del formaggio Parmigiano-Reggiano. Sci. Tecn. Latt. Cas. 27:208-216.

Martin, P., M. Szymanowska, L. Zwierzchowski, and C. Leroux. 2002. The impact of genetic polymorphisms on the protein composition of ruminant milks. Reprod. Nutr. Dev. 42:433-459.

Marzali, A. S., and K. F. Ng-Kwai-Hang. 1986. Effect of milk composition and genetic polymorphism on coagulation properties of milk. J. Dairy Sci. 69:1793-1799.

Mayer, H. K., M. Ortner, E. Tschager, and W. Ginzinger. 1997. Composite milk protein phenotypes in relation to composition and cheese making properties of milk. Int. Dairy J. 7:305-310.
Ng-Kwai-Hang, K. F., J. F. Hayes, J. E. Moxley, and H. G. Monardes. 1984. Associations of genetic variants of casein and milk serum proteins with milk, fat and protein production by dairy cattle. J. Dairy Sci. 67:835-840.

Ng-Kwai-Hang, K. F., J. F. Hayes, J. E. Moxley, and H. G. Monardes. 1986. Relationships between milk protein polymorphism and major milk constituents in Holstein-Friesian cows. J. Dairy Sci. 69:22-26.

Ojala, M., T. R. Famula, and J. F. Medrano. 1997. Effects of milk protein genotypes on the variation for milk production traits of Holstein and Jersey cows in California. J. Dairy Sci. 80:17761785 .

Ojala, M., A.-M. Tyrisevä, and T. Ikonen. 2005. Genetic improvement of milk quality traits for cheese production. Pages 307-311 in Indicators of Milk and Beef Quality. J. F. Hocquette and S. Gigli, ed. EAAP publication 112. Wageningen Academic Publishers, Wageningen, the Netherlands.

Pagnacco, G., and A. Caroli. 1987. Effect of casein and b-lactoglobulin genotypes on renneting properties of milks. J. Dairy Res. $54: 479-485$.

Politis, I., and K. F. Ng-Kwai-Hang. 1988. Effects of somatic cell counts and milk composition on the coagulating properties of milk. J. Dairy Sci. 71:1740-1745.

SAS Institute. 2000. User's Guide. SAS Institute Inc., Cary, NC.

Threadgill, D. W., and J. E. Womack. 1990. Genomic analysis of the major bovine milk protein genes. Nucleic Acids Res. 18:69356942.

Waugh, D. F., and P. H. von Hippel. 1956. k-Casein and stabilization of casein micelles. J. Am. Chem. Soc. 78:4576-4582. 